\title{
Optimalisasi Penugasan Karyawan Jasa Ekspedisi Menggunakan Metode Hungarian (Studi Kasus CV. Anteraja Cabang Mekarmukti)
}

\author{
Lutfi Nur Rahman ${ }^{1 *}$, Wahyudin ${ }^{2}$ \\ ${ }^{1,2}$ Teknik Industri, Universitas Singaperbangsa, Karawang \\ *Koresponden email: luthfi.nur17098@ student.unsika.ac.id
}

Diterima: 15 Juli 2021

Disetujui: 26 Juli 2021

\begin{abstract}
The Covid-19 pandemic has led to an increase in e-commerce orders that people prefer to purchase their requirements online. This impact occurs in the development of the freight forwarding services industry which takes a long time to deliver merchandise to consumers so delivery is not optimal on one day. CV. Anteraja Mekarmukti branch is one of the shipping service providers of the companies that has 14 couriers responsible for delivering parcels to 14 delivery points in Cikarang Baru. The problem that is often experienced by the branch CV. Anteraja Mekarmukti is related to the allocation of mail which leads to a long delivery delay. The method used in this study was the Hungarian Method to minimize time by placing courier delivery at destination. Based on the results of the survey, having used the Hungarian Method obtained the delivery deadline e on the CV. Anteraja is 172 minutes, where there is a 30-minute shorter delivery time of goods and time efficiency of $14.85 \%$ compared with to the completion time before using the Hungarian method of 202 minutes.
\end{abstract}

Keywords: operation research, linear programming, assignment problem, Hungarian method, delivery time.

\begin{abstract}
Abstrak
Pandemi Covid-19 telah mendorong peningkatan pesanan e-commerce karena masyarakat lebih memilih untuk membeli kebutuhannya secara online. Ini berdampak pada perkembangan industri jasa ekspedisi barang yang membutuhkan waktu pengiriman barang yang lama sampai ke konsumen sehingga pengiriman tidak optimal dalam satu hari. CV. Anteraja cabang Mekarmukti merupakan salah satu perusahaan ekspedisi penyedia jasa pengiriman dengan 14 kurir yang bertugas mengirimkan paket ke 14 titik pengantaran di Cikarang Baru. Permasalahan yang sering dialami CV. Anteraja cabang Mekarmukti yaitu berhubungan dengan alokasi kurir yang mengakibatkan waktu pengantaran menjadi lebih lama. Metode yang digunakan dalam penelitian ini adalah metode Hungarian untuk meminimalkan waktu dengan menempatkan kurir pengiriman sesuai tempat tujuan. Berdasarkan hasil penelitian, setelah menggunakan metode Hungarian diperoleh waktu pengiriman barang pada CV. Anteraja adalah 172 menit, dimana terjadi pengurangan waktu mengantarkan barang sebesar 30 menit dan efisiensi waktu sebanyak $14,85 \%$ jika dibandingkan waktu penyelesaian sebelum menggunakan metode Hungarian yaitu 202 menit.
\end{abstract}

Keywords: riset operasi, program linier, masalah penugasan, metode Hungarian, waktu pengantaran

\section{Pendahuluan}

Pandemi Covid-19 telah mendorong peningkatan pesanan e-commerce. Peningkatan belanja digital terjadi karena masyarakat lebih memilih untuk membeli kebutuhannya secara online, hal ini sejalan dengan penerapan kebijakan pemerintah untuk bekerja dari rumah atau Work From Home (WFH) dan sekolah dari rumah. Hal tersebut memberi dampak pada perkembangan industri jasa ekspedisi yang mengantarkan barang dari gudang sampai ke tangan konsumen. Pertumbuhan e-commerce dalam kondisi saat ini membuka peluang besar bagi jasa ekspedisi baik antar daerah, domestik maupun luar negeri, untuk dapat berkontribusi dalam proses pengiriman. Jasa kurir juga berperan penting dalam menunjang kelancaran bisnis perusahaan yang membutuhkan jasa pengiriman yang cepat dan aman.

Anteraja merupakan salah satu perusahaan ekspedisi penyedia jasa pengiriman yang menyediakan jasa pengiriman barang dari gudang dikirim ke tempat tujuan pelanggan. CV. Anteraja cabang Mekarmukti mempunyai 14 kurir yang bertugas mengirimkan paket ke 14 titik pengantaran di Cikarang Baru. Permasalahan yang sering dialami CV. Anteraja cabang Mekarmukti berhubungan dengan alokasi kurir dengan pengiriman yang harus diselesaikan. Dalam sebuah perusahaan atau industri, sumber daya terbatas mencakup semua faktor produksi seperti mesin, tenaga kerja, bahan baku, atau modal [1]. Saat 
menyelesaikan beberapa tugas yang ada, setiap pekerja memiliki tingkat produktivitas yang berbeda. Perbedaan ini dapat dipengaruhi oleh banyak faktor, antara lain kondisi fisik, pengetahuan, pengalaman, minat, dan kepribadian karyawan [2]. Oleh karena itu, perusahaan perlu melakukan Masalah lain adalah bahwa jumlah yang dikeluarkan oleh karyawan yang ada untuk pekerjaan tertentu dapat bervariasi. Masalah tersebut merupakan masalah penugasan (assignment problem).

Masalah penugasan (assignment problem) adalah suatu masalah mengenai pengaturan objek untuk melaksanakan tugas, dengan tujuan meminimalkan biaya, waktu, jarak, dan sebagainya ataupun memaksimalkan keuntungan yang salah satu penyelesaiannya menggunakan metode Hungarian [3]. Masalah penugasan merupakan masalah khusus dari pemrograman linier (linear programming). Pemrograman linier adalah bagian dari matematika terapan yang dapat digunakan untuk memecahkan masalah pengalokasian sumber-sumber yang terbatas secara optimal[4]. Jika pekerja dianggap sebagai sumber dan alokasi dianggap sebagai tujuan, maka model alokasi akan sama dengan masalah transportasi, di mana jumlah sumber dan tujuan sama, hanya satu untuk setiap sumber, dan sama untuk setiap tujuan hanya satu yang dibutuhkan [5]. Dalam mengoptimalkan waktu pengiriman barang dan membuatnya sesuai dengan tujuan pengiriman, metode Hungarian yang akan digunakan.

Pada [6] dilakukan penugasan operator mesin produksi menggunakan metode Hungarian untuk memaksimalkan hasil produksi. Penelitian [7] hasil perhitungan menggunakan metode Hungarian menghasilkan realisasi produksi yang lebih besar dibandingkan tahun sebelumnya.

\section{Metode Penelitian}

Penelitian ini menggunakan objek penelitian yaitu kurir pengiriman CV. Anteraja cabang Mekarmukti. Data diperoleh melalui wawancara dan observasi dengan karyawan CV. Anteraja cabang Mekarmukti. Metode yang digunakan dalam penelitian ini adalah metode Hungarian untuk meminimalkan waktu dengan menempatkan kurir pengiriman pada tempat tujuan.

\section{Metode Masalah Penugasan (Assignment Problem)}

Metode pemberian penugasan suatu pekerjaan atau job sumber daya untuk meminimalkan total biaya atau diperlukan untuk melakukan tugas yang sedang berlangsung jalannya [8]. Masalah penugasan adalah masalah pengaturan pada individu (benda) untuk melaksanakan tugas (kegiatan), sehingga biaya yang dikeluarkan untuk pelaksanaan penugasan dapat diminimalkan [9]. Masalah penugasan (assignment problem) adalah suatu masalah mengenai pengaturan objek untuk melaksanakan tugas, dengan tujuan meminimalkan biaya, waktu, jarak, dan sebagainya ataupun memaksimalkan keuntungan [10]. Masalah penugasan merupakan kasus khusus dari model transportasi, di mana sejumlah sumber akan ditugaskan ke tujuan (satu sumber hanya untuk satu tujuan, dan sebaliknya) sehingga total biaya minimal [11].

Sumber yang dimaksud biasanya berupa pekerja (suatu pekerjaan), sedangkan tujuannya adalah mesin. Dapat diilustrasikan, ada $m$ pekerjaan yang diberikan kepada $n$ mesin, dimana $i(i=1,2,3, \ldots m)$ sebagai pekerja atau pekerjaan yang ditugaskan kepada $j(j=1,2,3, \ldots n)$ sebagai mesin yang tersedia, sehingga diperoleh $c_{i j}$ sebagai total biaya penugasan. Maka, input atau masukan yang digunakan untuk masing-masing sumber yang ada adalah 1 (atau $\alpha_{1}=1$ untuk seluruh $i$ ). Demikian juga dengan input mesin, karena satu mesin hanya dapat menerima satu jenis pekerjaan saja, maka demand atau permintaan dari setiap tujuan adalah 1 (atau $b_{1}=1$ untuk seluruh $j$ ). Ada $\mathrm{n}$ ! (n faktorial) penugasan yang mungkin dalam suatu masalah [12]. Masalah penugasan membahasa tentang pengaturan pada objek untuk melaksanakan tugas, sehingga dengan demikian biaya atau waktu yang dikeluarkan untuk pelaksanaan penugasan tersebut dapat diminimalkan. Masalah penugasan dapat ditulis dalam bentuk matematika sebagai berikut [13].

$\operatorname{Min} \sum_{i=1}^{m} \sum_{j=1}^{n} C_{i j} X_{i j}$

Dengan batasan,

$$
\sum_{j=1}^{n} X_{i j}=1 \text {, untuk i= } 1,2, . ., \mathrm{n},
$$

Dengan,

$$
\begin{aligned}
& \sum_{j=1}^{m} X_{i j}=1, \text { untuk } \mathrm{i}=1,2, \ldots, \mathrm{m} \\
& X_{i j}=0 \text { atau } 1 \text {, dan }
\end{aligned}
$$

$$
\begin{aligned}
& X_{i j} \text { : Penugasan dari sumber i ke tujuan } \mathrm{j} \\
& C_{i j} \text { : Satuan ukur dari sumber i ke tujuan } \mathrm{j}
\end{aligned}
$$

Masalah penugasan dalam keadaan tertentu akan mengalami cacah penugasan, dimana jumlah $m \neq$ $n$. Hal tersebut dapat teratasi dengan cara menambahkan dummy worker atau dummy job [14]. 


\section{Metode Hungarian}

Metode Hungarian adalah salah satu metode penugasan assignment mengasumsikan bahwa, harus ada kecocokan antara sumber pasokan atau pasokan (supply sumber) dengan kebutuhan atau permintaan (demand), dalam arti banyaknya pekerjaan dengan mesin yang akan memproses pekerjaan yang seimbang [15]. Metode Hungarian adalah metode yang memodifikasi baris dan kolom dalam matriks efektivitas sampai muncul sebuah komponen nol tunggal dalam setiap baris atau kolom yang dapat dipilih sebagai alokasi penugasan. Semua alokasi penugasan yang dibuat adalah alokasi yang optimal, dan saat diterapkan pada matriks efektivitas awal, maka akan memberikan hasil penugasan yang paling minimum[5]. Adapun syarat-syarat metode Hungarian, yaitu[16]:

a. Jumlah $i$ harus sama dengan jumlah $j$ yang harus diselesaikan.

b. Setiap sumber hanya mengerjakan satu tugas.

c. Apabila jumlah sumber tidak sama dengan jumlah tugas atau sebaliknya, maka ditambahkan variabel dummy woker atau dummy job.

d. Terdapat dua permasalahan yang diselesaikan yaitu meminimumkan kerugian (biaya, waktu, jarak dan sebagainya) atau memaksimumkan keuntungan.

Penggunaan prosedur metode Hungarian dengan matriks berbobot terdiri dari 3 langkah, yaitu menyusun matriks penugasan, menganalisis kelayakan penentuan nilai optimal, dan menyusun ulang matriks. Langkah-langkah penyelesaian metode Hungarian adalah sebagai berikut [17].

a. Menyusun matriks penugasan. Jumlah baris sama dengan jumlah kolom, yang memenuhi asumsi. Jika tidak sama, diperlukan dummy.

b. Pilih nilai terkecil dari setiap baris, lalu lakukan operasi pengurangan pada setiap nilai dengan angka terkecil di baris tersebut. Oleh karena itu, dapat dipastikan bahwa setidaknya satu elemen di setiap baris matriks adalah nol dan tidak ada elemen dengan nilai negative.

c. Jika tidak ada kolom dengan elemen 0 , mengurangkan kolom adalah dengan memilih nilai terkecil dari kolom tersebut, kemudian melakukan pengurangan dari setiap nilai kolom yang memiliki angka terkecil yang telah dipilih. Oleh karena itu, dapat dipastikan bahwa setidaknya satu elemen di setiap baris dan kolom pada matriks adalah nol dan tidak ada elemen dengan nilai negative.

d. Distribusi optimal ditentukan dengan menggambar garis horizontal dan vertikal yang melewati semua sel dengan nilai 0. Apabila jumlah garis sama dengan jumlah baris dan kolom maka alokasinya sudah optimal. Jika tidak, maka harus dilakukan tahap revisi.

e. Tahap revisi yaitu dengan memilih nilai minimum yang tidak dilintasi garis kemudian dikurangi semua nilai yang tidak dilintasi garis. Kemudian tambahkan dengan angka yang terdapat pada perpotongan garis tersebut.

f. Alokasi ditempatkan dalam sel dengan nilai 0. Setiap 0 diganti dengan 1 tetapi hanya ada satu angka 1 per kolom dan baris sebagai tugas.

g. Nilai total solusi dihitung sesuai dengan elemen matriks awal yang belum direduksi, sehingga diperoleh nilai total optimal.

\section{Hasil dan Pembahasan}

Data yang diperoleh dari CV. Anteraja cabang Mekarmukti berupa waktu penyelesaian yang dibutuhkan masing-masing kurir untuk menyelesaikan pengiriman barang ke 14 titik lokasi di Cikarang Baru. Waktu penyelesaian tersebut dihitung dari waktu perjalanan dari masing-masing kurir dalam mengantarkan barang dari kantor CV. Anteraja cabang Mekarmukti seperti dapat dilihat pada Tabel 1. 
Tabel 1. Waktu pengiriman barang (menit)

\begin{tabular}{|c|c|c|c|c|c|c|c|c|c|c|c|c|c|c|}
\hline Tujuan & Ali & Hendra & Aji & Firman & Indra & Levi & Rizki & Ucup & Ayong & Agus & Ipul & Yasin & Supto & Edi \\
\hline Kp.Rawalintah & 10 & 8 & 9 & 13 & 11 & 15 & 14 & 11 & 15 & 13 & 14 & 14 & 8 & 13 \\
\hline $\begin{array}{c}\text { Kp.Warung } \\
\text { Kobak }\end{array}$ & 13 & 15 & 18 & 17 & 11 & 17 & 10 & 14 & 11 & 17 & 12 & 15 & 16 & 10 \\
\hline Kp. Pulokapuk & 11 & 10 & 14 & 9 & 14 & 15 & 12 & 11 & 9 & 14 & 13 & 9 & 10 & 13 \\
\hline $\begin{array}{c}\text { Perum Graha } \\
\text { Karya }\end{array}$ & 14 & 11 & 15 & 16 & 15 & 11 & 15 & 14 & 13 & 11 & 22 & 16 & 17 & 15 \\
\hline $\begin{array}{l}\text { Perum Mekar } \\
\text { Indah }\end{array}$ & 17 & 15 & 16 & 15 & 18 & 20 & 21 & 20 & 19 & 15 & 20 & 18 & 19 & 18 \\
\hline $\begin{array}{c}\text { Perumahan } \\
\text { Beruang }\end{array}$ & 20 & 22 & 17 & 22 & 19 & 23 & 17 & 21 & 19 & 21 & 20 & 21 & 18 & 21 \\
\hline $\begin{array}{l}\text { Perumahan } \\
\text { Kelkinci }\end{array}$ & 19 & 18 & 22 & 19 & 18 & 25 & 24 & 22 & 20 & 24 & 20 & 22 & 25 & 24 \\
\hline $\begin{array}{l}\text { Kp. Pasir } \\
\text { Limus }\end{array}$ & 12 & 9 & 15 & 12 & 14 & 17 & 11 & 10 & 14 & 11 & 9 & 14 & 10 & 13 \\
\hline $\begin{array}{l}\text { Kp. Tegal } \\
\text { Danas }\end{array}$ & 22 & 19 & 25 & 20 & 23 & 21 & 20 & 22 & 19 & 21 & 23 & 25 & 22 & 21 \\
\hline Kp. Panjalin & 15 & 13 & 17 & 12 & 16 & 18 & 18 & 11 & 17 & 15 & 23 & 16 & 17 & 15 \\
\hline $\begin{array}{l}\text { Kp. Mangun } \\
\text { Harja }\end{array}$ & 13 & 10 & 18 & 19 & 16 & 19 & 15 & 16 & 12 & 11 & 17 & 15 & 16 & 11 \\
\hline Kp. Tegal Gede & 16 & 15 & 19 & 14 & 14 & 15 & 16 & 19 & 16 & 15 & 17 & 15 & 17 & 15 \\
\hline $\begin{array}{c}\text { Kawasan } \\
\text { Jababeka } 1\end{array}$ & 10 & 13 & 8 & 11 & 14 & 12 & 10 & 11 & 12 & 12 & 15 & 11 & 10 & 8 \\
\hline $\begin{array}{c}\text { Kawasan } \\
\text { Jababeka } 2\end{array}$ & 15 & 14 & 14 & 12 & 19 & 18 & 14 & 13 & 19 & 16 & 19 & 18 & 13 & 16 \\
\hline
\end{tabular}

Sumber: CV. Anteraja (2020)

Sebelum menggunakan metode Hungarian, waktu yang dibutuhkan kurir CV. Anteraja untuk menyelesaikan setiap pengiriman yang ada disajikan pada Tabel 2.

Tabel 2. Waktu pengiriman barang sebelum menggunakan metode Hungarian

\begin{tabular}{llc}
\hline \multicolumn{1}{c}{ Karyawan } & \multicolumn{1}{c}{ Tujuan } & Waktu (Menit) \\
\hline Ali & Perumahan Beruang & 20 \\
Hendra & Perumahan Kelinci & 18 \\
Aji & Kp. Tegal Gede & 19 \\
Firman & Perum Mekar Indah & 15 \\
Indra & Kp. Rawalintah & 11 \\
Levi & Kp. Tegal Danas & 21 \\
Rizki & Kp. Mangun Harja & 15 \\
Ucup & Kp. Panjalin & 11 \\
Ayong & Perum Graha Karya & 13 \\
Agus & Kawasan Jababeka 1 & 12 \\
Ipul & Kp. Warung Kobak & 12 \\
Yasin & Kp. Pulokapuk & 9 \\
Supto & Kp.Pasir Limus & 10 \\
Edi & Kawasan Jababeka 2 & 16 \\
\hline Total Waktu & & 202 \\
\hline & Sumber: CV. Anteraja (2020)
\end{tabular}

Langkah-langkah metode Hungarian sebagai berikut:

1. Menyusun matriks penugasan. Jumlah baris sama dengan jumlah kolom, yang memenuhi asumsi. Jika tidak sama, diperlukan dummy. 


$$
\left[\begin{array}{ccccccccccccccc} 
& P_{1} & P_{2} & P_{3} & P_{4} & P_{5} & P_{6} & P_{7} & P_{8} & P_{9} & P_{10} & P_{11} & P_{12} & P_{13} & P_{14} \\
T_{1} & 10 & 8 & 9 & 13 & 11 & 15 & 14 & 11 & 15 & 13 & 14 & 14 & 8 & 13 \\
T_{2} & 13 & 15 & 18 & 17 & 11 & 17 & 10 & 14 & 11 & 17 & 12 & 15 & 16 & 10 \\
T_{3} & 11 & 10 & 14 & 9 & 14 & 15 & 12 & 11 & 9 & 14 & 13 & 9 & 10 & 13 \\
T_{4} & 14 & 11 & 15 & 16 & 15 & 11 & 15 & 14 & 13 & 11 & 22 & 16 & 17 & 15 \\
T_{5} & 17 & 15 & 16 & 15 & 18 & 20 & 21 & 20 & 19 & 15 & 20 & 18 & 19 & 18 \\
T_{6} & 20 & 22 & 17 & 22 & 19 & 23 & 17 & 21 & 19 & 21 & 20 & 21 & 18 & 21 \\
T_{7} & 19 & 18 & 22 & 19 & 18 & 25 & 24 & 22 & 20 & 24 & 20 & 22 & 25 & 24 \\
T_{8} & 12 & 9 & 15 & 12 & 14 & 17 & 11 & 10 & 14 & 11 & 9 & 14 & 10 & 13 \\
T_{9} & 22 & 19 & 25 & 20 & 23 & 21 & 20 & 22 & 19 & 21 & 23 & 25 & 22 & 21 \\
T_{10} & 15 & 13 & 17 & 12 & 16 & 18 & 18 & 11 & 17 & 15 & 23 & 16 & 17 & 15 \\
T_{11} & 13 & 10 & 18 & 19 & 16 & 19 & 15 & 16 & 12 & 11 & 17 & 15 & 16 & 11 \\
T_{12} & 16 & 15 & 19 & 14 & 14 & 15 & 16 & 19 & 16 & 15 & 17 & 15 & 17 & 15 \\
T_{13} & 10 & 13 & 8 & 11 & 14 & 12 & 10 & 11 & 12 & 12 & 15 & 11 & 10 & 8 \\
T_{14} & 15 & 14 & 14 & 12 & 19 & 18 & 14 & 13 & 19 & 16 & 19 & 18 & 13 & 16
\end{array}\right]
$$

Karena jumlah dan tujuan pekerja sama, dapat dikatakan permasalahan ini sudah seimbang.

2. Pilih nilai terkecil dari setiap baris, lalu lakukan operasi pengurangan pada setiap nilai dengan angka terkecil di baris tersebut. Oleh karena itu, dapat dipastikan bahwa setidaknya satu elemen di setiap baris matriks adalah nol dan tidak ada elemen dengan nilai negative.

$$
\left[\begin{array}{rrrrrrrrrrrrrr}
2 & 0 & 1 & 5 & 3 & 7 & 6 & 3 & 7 & 5 & 6 & 6 & 0 & 5 \\
3 & 5 & 5 & 8 & 7 & 7 & 0 & 4 & 1 & 7 & 2 & 5 & 6 & 0 \\
2 & 1 & 5 & 0 & 5 & 6 & 3 & 2 & 0 & 5 & 4 & 0 & 1 & 4 \\
3 & 0 & 4 & 5 & 4 & 0 & 4 & 3 & 2 & 0 & 11 & 5 & 6 & 4 \\
2 & 0 & 1 & 0 & 3 & 5 & 6 & 5 & 4 & 0 & 5 & 3 & 4 & 3 \\
3 & 5 & 0 & 5 & 2 & 6 & 0 & 4 & 2 & 4 & 3 & 4 & 1 & 4 \\
1 & 0 & 4 & 1 & 0 & 7 & 6 & 4 & 2 & 6 & 2 & 4 & 7 & 6 \\
3 & 0 & 6 & 3 & 5 & 8 & 2 & 1 & 5 & 2 & 0 & 5 & 1 & 4 \\
3 & 0 & 6 & 1 & 4 & 2 & 1 & 3 & 0 & 2 & 4 & 6 & 3 & 2 \\
4 & 2 & 6 & 1 & 5 & 7 & 7 & 0 & 6 & 4 & 12 & 5 & 6 & 4 \\
3 & 0 & 8 & 9 & 6 & 9 & 5 & 6 & 2 & 1 & 7 & 5 & 6 & 1 \\
2 & 1 & 5 & 0 & 0 & 1 & 2 & 5 & 2 & 1 & 3 & 1 & 3 & 1 \\
2 & 5 & 0 & 3 & 6 & 4 & 2 & 3 & 4 & 4 & 7 & 3 & 2 & 0 \\
3 & 2 & 2 & 0 & 7 & 6 & 2 & 1 & 7 & 4 & 7 & 6 & 1 & 4
\end{array}\right]
$$

3. Jika tidak ada kolom dengan elemen 0 , mengurangkan kolom adalah dengan memilih nilai terkecil dari kolom tersebut, kemudian melakukan pengurangan dari setiap nilai kolom yang memiliki angka terkecil yang telah dipilih. Oleh karena itu, dapat dipastikan bahwa setidaknya satu elemen di setiap baris dan kolom pada matriks adalah nol dan tidak ada elemen dengan nilai negative.

$$
\left[\begin{array}{cccccccccccccc}
2 & 0 & 1 & 5 & 3 & 7 & 6 & 3 & 7 & 5 & 6 & 6 & 0 & 5 \\
3 & 5 & 5 & 8 & 7 & 7 & 0 & 4 & 1 & 7 & 2 & 5 & 6 & 0 \\
2 & 1 & 5 & 0 & 5 & 6 & 3 & 2 & 0 & 5 & 4 & 0 & 1 & 4 \\
3 & 0 & 4 & 5 & 4 & 0 & 4 & 3 & 2 & 0 & 11 & 5 & 6 & 4 \\
2 & 0 & 1 & 0 & 3 & 5 & 6 & 5 & 4 & 0 & 5 & 3 & 4 & 3 \\
3 & 5 & 0 & 5 & 2 & 6 & 0 & 4 & 2 & 4 & 3 & 4 & 1 & 4 \\
1 & 0 & 4 & 1 & 0 & 7 & 6 & 4 & 2 & 6 & 2 & 4 & 7 & 6 \\
3 & 0 & 6 & 3 & 5 & 8 & 2 & 1 & 5 & 2 & 0 & 5 & 1 & 4 \\
3 & 0 & 6 & 1 & 4 & 2 & 1 & 3 & 0 & 2 & 4 & 6 & 3 & 2 \\
4 & 2 & 6 & 1 & 5 & 7 & 7 & 0 & 6 & 4 & 12 & 5 & 6 & 4 \\
3 & 0 & 8 & 9 & 6 & 9 & 5 & 6 & 2 & 1 & 7 & 5 & 6 & 1 \\
2 & 1 & 5 & 0 & 0 & 1 & 2 & 5 & 2 & 1 & 3 & 1 & 3 & 1 \\
2 & 5 & 0 & 3 & 6 & 4 & 2 & 3 & 4 & 4 & 7 & 3 & 2 & 0 \\
3 & 2 & 2 & 0 & 7 & 6 & 2 & 1 & 7 & 4 & 7 & 6 & 1 & 4
\end{array}\right]
$$


Setelah mengurangi kolom pertama, sudah ada nol entri di setiap kolom dan setiap baris. Hasilnya adalah matriks berikut.

$$
\left[\begin{array}{rrrrrrrrrrrrrr}
1 & 0 & 1 & 5 & 3 & 7 & 6 & 3 & 7 & 5 & 6 & 6 & 0 & 5 \\
2 & 5 & 5 & 8 & 7 & 7 & 0 & 4 & 1 & 7 & 2 & 5 & 6 & 0 \\
1 & 1 & 5 & 0 & 5 & 6 & 3 & 2 & 0 & 5 & 4 & 0 & 1 & 4 \\
2 & 0 & 4 & 5 & 4 & 0 & 4 & 3 & 2 & 0 & 11 & 5 & 6 & 4 \\
1 & 0 & 1 & 0 & 3 & 5 & 6 & 5 & 4 & 0 & 5 & 3 & 4 & 3 \\
2 & 5 & 0 & 5 & 2 & 6 & 0 & 4 & 2 & 4 & 3 & 4 & 1 & 4 \\
0 & 0 & 4 & 1 & 0 & 7 & 6 & 4 & 2 & 6 & 2 & 4 & 7 & 6 \\
2 & 0 & 6 & 3 & 5 & 8 & 2 & 1 & 5 & 2 & 0 & 5 & 1 & 4 \\
2 & 0 & 6 & 1 & 4 & 2 & 1 & 3 & 0 & 2 & 4 & 6 & 3 & 2 \\
3 & 2 & 6 & 1 & 5 & 7 & 7 & 0 & 6 & 4 & 12 & 5 & 6 & 4 \\
2 & 0 & 8 & 9 & 6 & 9 & 5 & 6 & 2 & 1 & 7 & 5 & 6 & 1 \\
1 & 1 & 5 & 0 & 0 & 1 & 2 & 5 & 2 & 1 & 3 & 1 & 3 & 1 \\
1 & 5 & 0 & 3 & 6 & 4 & 2 & 3 & 4 & 4 & 7 & 3 & 2 & 0 \\
2 & 2 & 2 & 0 & 7 & 6 & 2 & 1 & 7 & 4 & 7 & 6 & 1 & 4
\end{array}\right]
$$

4. Distribusi optimal ditentukan dengan menggambar garis horizontal dan vertikal yang melewati semua sel dengan nilai 0. Apabila jumlah garis sama dengan jumlah baris dan kolom maka alokasinya sudah optimal. Jika tidak, maka harus dilakukan tahap revisi.

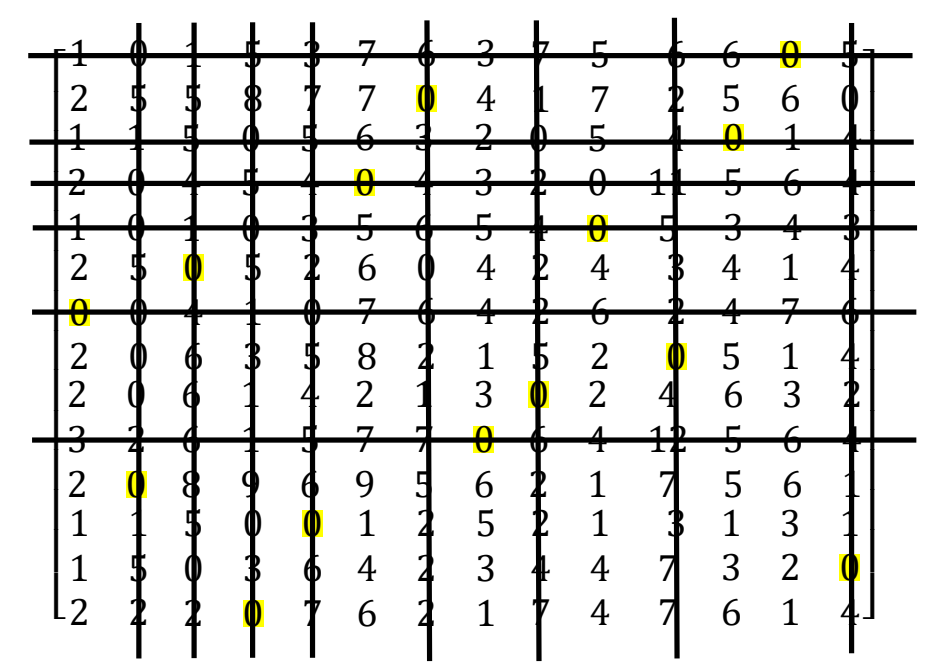

Karena matriks menunjukkan bahwa jumlah garis yang mencakup semua 0 entri sama dengan jumlah baris atau kolom, maka alokasinya sudah optimal. Dengan demikian, penentuan alokasi dapat diselesaikan.

5. Nilai total solusi dihitung sesuai dengan elemen matriks awal yang belum direduksi, sehingga diperoleh nilai total optimal.

Solusi keputusan yang diperoleh sebagai berikut:

$$
\begin{aligned}
Z & =\sum_{i=1}^{m} \sum_{j=1}^{n} C_{i j} X_{i j}=X, \\
Z & =X_{1,13}+X_{2,7}+X_{3,12}+X_{4,6}+X_{5,10}+X_{6,3}+X_{7,1}+X_{8,11}+X_{9,9}+X_{10,8}+X_{11,2}+X_{12,5}+X_{13,14}+X_{14,4} \\
& =8+10+9+11+15+17+19+9+19+11+10+14+8+12 \\
& =172
\end{aligned}
$$

Berdasarkan hasil perhitungan metode Hungarian diperoleh total waktu optimal yaitu 172 menit, dan pengaturan penugasan ditunjukkan pada Tabel 3. 
Tabel 3. Waktu pengiriman barang setelah menggunakan metode Hungarian

\begin{tabular}{llc}
\multicolumn{1}{c}{ Karyawan } & \multicolumn{1}{c}{ Tujuan } & Waktu (Menit) \\
\hline Ali & Perumahan Kelinci & 19 \\
Hendra & Kp. Mangun Harja & 10 \\
Aji & Perumahan Beruang & 17 \\
Firman & Kawasan Jababeka 2 & 12 \\
Indra & Kp. Tegal Gede & 14 \\
Levi & Perum Graha Karya & 11 \\
Rizki & Kp. Warung Kobak & 10 \\
Ucup & Kp. Panjalin & 11 \\
Ayong & Kp. Tegal Danas & 19 \\
Agus & Perum Mekar Indah & 15 \\
Ipul & Kp.Pasir Limus & 9 \\
Yasin & Kp. Pulokapuk & 9 \\
Supto & Kp. Rawalintah & 8 \\
Edi & Kawasan Jababeka 1 & 8 \\
\hline Total Waktu & & 172 \\
\hline & Sumber: CV. Anteraja (2020)
\end{tabular}

Efisiensi waktu pengantaran barang dapat dihitung seperti berikut.

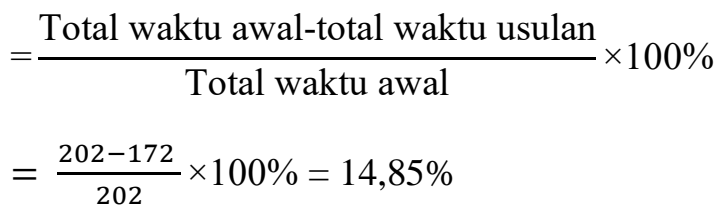

\section{Kesimpulan}

Berdasarkan hasil perhitungan, total waktu yang dibutuhkan oleh kurir CV. Anteraja cabang Mekarmukti dalam perjalanan pengiriman barang sebelum menggunakan metode Hungarian adalah 202 menit. Sedangkan, total waktu yang diperlukan untuk pengiriman setelah menggunakan metode Hungarian adalah 172 menit. Dapat dilihat bahwa terdapat pengurangan waktu perjalanan mengantarkan barang sebesar 30 menit dengan efisiensi waktu pengantaran barang sebesar 14,85\%. Dapat disimpulkan bahwa pengalokasian kurir pada CV. Anteraja cabang Mekarmukti setelah menggunakan metode Hungarian dapat mengoptimalkan total waktu perjalanan dalam mengantarkan barang.

Pengalokasian kurir yang efektif, yaitu Ali ke Perumahan Kelinci, Hendra ke Kp. Mangun Harja, Aji ke Perumahan Beruang, Firman ke Kawasan Jababeka 2, Indra ke Kp.Tegal Gede, Levi ke Perum Graha Karya, Rizki ke Kp. Warung Kobak, Ucup ke Kp. Panjalin, Ayong ke Kp.Tegal Danas, Agus ke Perum Mekar Indah, Ipul ke Kp. Pasir Limus, Yasin ke Kp. Pulokapuk, Suptu ke Kp. Rawalintah, dan Edi ke Kawasan Jababeka 1.

\section{Daftar Pustaka}

[1] D. . Syaifuddin, Riset Operasi (Aplikasi Quantitative Analysis for Management). Malang: CV Citra Malang, 2011.

[2] Y. G. G. Sujati, "Kepuasan Kerja: Arti Penting, Faktor-Faktor Yang Mempengaruhi dan Implikasinya Bagi Organisasi,” J. Pendidik. Ekon., pp. 1-60, 2018.

[3] N. H. N. Wirum, "Optimasi Pembagian Tugas Karyawan Menggunakan Metode Hungarian (Studi Kasus : Karyawan Grand Sony Tailor Makassar)," Universitas Islam Negeri Alauddin Makassar, 2017.

[4] E. Rahmawati, N. Satyahadewi, F. Intisari, K. Kunci, M. Biaya, and H. Kuhn, "Optimalisasi Masalah Penugasan Menggunakan Metode Hungarian (Studi kasus pada PT Pos Indonesia (Persero) Pontianak)," Bul. Ilm. Mat. Stat. danTerapannya, vol. 04, no. 3, pp. 363-370, 2015.

[5] S. E. Purba, "Analisis Beberapa Metode Transportasi Dalam Optimalisasi Biaya Distribusi," Universitas Sumatera Utara, 2016. 
[6] W. O. Widyarto and D. Triana, "Penugasan Operator Mesin Produksi dengan Menggunakan Metode Hungarian dan Algoritma Generate and Test," J. Intech Tek. Ind., vol. 1, no. 1, pp. 1-9, 2015.

[7] N. Husniati, J. A. Judiarni, and Doddy Adhimursandi, "Analisis Assigment Problem Berdasarkan Penilaian Kinerja Karyawan Menggunakan Metode Hungarian (Hungarian Method) dan Pohon Keputusan (Decision Tree)," J. Manaj., vol. 9, no. 1, p. 2, 2017.

[8] Masram and Mu'ah, Manajemen Sumber Daya Manusia. Zifatama Publisher, 2015.

[9] S. Bariasti and A. Lestari, "Penyelesaian Masalah Penugasan Menggunakan Metode Hungarian dan Pinalti," Sains Mat. dan Stat., vol. 3, no. 1, p. 1, 2017, [Online]. Available: http://ejournal.uinsuska.ac.id/index.php/JSMS/article/view/4470.

[10] B. T. Mulyono and T. Rully, "Meningkatkan Efisiensi Proses Produksi Sepatu Heels Pada Vivan Shoes," J. Online Mhs. Bid. Manaj., vol. 4 (4), 2019.

[11] R. Evipania, G. K. Gandhiadi, and I. W. Sumarjaya, "Optimalisasi Masalah Penugasan Tidak Seimbang Menggunakan Modified Hungarian Method," E-Jurnal Mat., vol. 10, no. 1, p. 26, 2021.

[12] D. Harini, "Optimasi Penugasan Menggunakan Metode Hungarian," Intensif, vol. 1, no. 2, p. 68, 2017, doi: 10.29407/intensif.v1i2.797.

[13] J. P. Assiddiq, "Optimalisasi Pembagian Pekerja Bangunan Menggunakan Metode Hungarian ( Studi Kasus Pada CV MHTdi Tanggul ) (Optimalisasi Of Construction Workers Using Hungarian Method ( Study Case at CV MHT Tanggul )," pp. 1-4, 2014.

[14] A. S. Sitio, "Perancangan Dan Implementasi Sistem Penugasan Pegawai Pada Dinas Ketahanan Pangan Dengan Metode Hungarian," J. Inform. Pelita Nusant., vol. 1, no. 1, p. 2, 2016.

[15] Muhardi, Manajemen Operasi: Suatu pendekatan kuantitatif untuk pengambilan keputusan. Bandung: PT Refika Aditama, 2011.

[16] R. A. Nika, "Tracking Pemain Sepakbola Menggunakan Metode Kalman Filter Berbasis TwoStages Hungarian Algorithm," 2017.

[17] M. Paendong and J. D. Prang, "Optimisasi Pembagian Tugas Karyawan Menggunakan Metode Hungarian,” J. Ilm. Sains, vol. 11, no. 1, p. 109, 2011. 